\title{
The role of neem leaves as organic pesticides in chili pepper (Capsicum frutescens)
}

\author{
SOPIALENA ${ }^{1, \bullet}$, SURYA SILA $^{1}$, ROSFIANSYAH $^{1}$, JULI NURDIANA $^{2, \bullet \bullet}$ \\ ${ }^{1}$ Program of Plant Pests and Disease Science, Faculty of Agriculture, Universitas Mulawarman. Jl. Pasir Belengkong, Kampus Gunung Kelua, Samarinda \\ 75123, East Kalimantan, Indonesia. Tel.: +62-541-749161, Fax.: +62-541-738341. `email: sopialena88@ gmail.com \\ ${ }^{2}$ Program of Environmental Study, Faculty of Engineering, Universitas Mulawarman. Jl. Sambaliung No. 9, Kampus Gunung Kelua, Samarinda 75123 , \\ East Kalimantan, Indonesia. Tel.: +62-541-749315, Fax.: +62-541-736834.``email: julinurdiana@ gmail.com
}

Manuscript received: 9 August 2018. Revision accepted: 24 October 2018

\begin{abstract}
Sopialena, Sila S, Rosfiansyah, Nurdiana J. 2018. The role of neem leaves as organic pesticides in chili pepper (Capsicum frutescens). Nusantara Bioscience 10: 246-250. The agricultural crops and horticultural plants are always under constant assault caused by diseases, insect pests, viruses, and other pathogens which may substantially reduce yield. Chili Pepper (Capsicum annum L.) is a popular horticultural plant of the Solanaceae family in Indonesia. Some serious diseases widely found in chili peppers, are anthracnose (Colletotrichum capsici), leaf spot (Cercospora capsici) and fruit rot (Phytophthora capsici). To manage the potential problems, this study is aimed to provide an explanatory knowledge of the use of plant-based pesticide to control the diseases in chili peppers. The information is meant to fill the knowledge gaps in the use of plant-based pesticide to control the chili diseases. The use of nonchemical pesticide benefits not only the environment but also as an organic strategy for disease management. This research used a randomized complete block design (RCBD) categorized into four groups and six different treatments. The organic pesticides were prepared from the extract of neem leaves, soursop leaves, lemongrass extract, tuba root extract, and kenikir/Cosmos caudatus extract). The result indicates that neem leaves are the most effective organic pesticides to control the chili pepper disease in Indonesia.
\end{abstract}

Keywords: chili peppers, neem leaves, lemongrass, tuba roots, soursop, kenikir

\section{INTRODUCTION}

Chili pepper (Capsicum frutescens L.) is well known for its use in various preparation such as kitchen spices, medicinal herbs (pharmaceutical industry), cosmetics industry, and food color). It contains quite complete nutrients, i.e., the calories, proteins, fats, carbohydrates, minerals, vitamins and other important medicinal substances (Kantar et al. 2016). Despite its greater economic value, chili pepper experiences a high risk of product failure. One of the main cause is the pathogen attack, which can lead to loss of production and reduce the quality (Ahmed et al. 2012; Fatima et al. 2015; Ferniah et al. 2015). In this regard, the production management is very important for farmers as it affects the quality and the quantity of chili peppers (Thakur et al. 2018).

Zhu et al. (2011) and Thakur et al (2018) reveals that any type of chili, either planted in lowland or highland, may suffer from the disease attacks. Pathogens' attack becomes one of the causes of a disease that can survive in seeds and infect the host plants. For instance, fungal disease may influence the plant growth, and reduce the quality and quantity of crop production up to $100 \%$ (Syamsuddin 1986; Zaheer 2012). Rahman et al. (2011) and Rabindranath et al. (2016) also identified the Anthracnose disease caused by Colletotrichum capsici fungi and Cercospora fungi which instigate the leaf spot in pepper plant in lowland areas up to the plateau. Further, it is also notable that the disease is not only attacking in planting phase but also infecting at storing period. The damage may vary ranging from $5-65 \%$ depends on the growing season and the intensity of preventive measure. As part of the production management, the use of chemical pesticides is still a reliable way for farmers to maintain the plant health, though not all the farmers manage it wisely. According to Chopan and Littenberg (2017) there are many ways to control the disease. Though, the chemical control is still favorable in Indonesia as it brings short visible results (Muzemu et al. 2011; Saxena et al. 2016; Suyadi et al. 2017), in developed countries such as America, Britain, and Japan, the chemical treatments are avoided, mainly because of the increasing environmental concerns and its development of resistance (Zhu et al. 2011; Reddy and Sasikala 2013; Pahla et al. 2014) in pathogens. In this regard, there is a growing approach to turn to nonchemical control and other relatively secure means, i.e., organic/plant-based/ botanical pesticide (Ahmad 2011; Sarwar 2013; Sarwar 2015).

Though there are many discussions on the use of organic pesticides (Sopialena 2014; Sopialena 2016), there are few studies that focus on the comparison of the use of organic pesticides to control the disease in chili pepper. Therefore, this study tries to bring up the discourse by comparing the efficacy of different type of organic pesticides, i.e., the extract of neem (or mimba) leaves (Azadirachta indica A. Juss), soursop leaves (Annona muricata L), lemongrass/serai (Cymbopogon citratus) extract, tuba root (Derris elliptica) extract, and kenikir 
(Cosmos caudatus) extract in reducing the sign of leaf spot disease and in growth and the production of chili pepper (Capsicum frutescens).

\section{MATERIALS AND METHODS}

\section{Research design}

This study used Randomized Block Design (RAK), which was divided into 6 treatments and 4 groups. The treatments were as follows: $\mathrm{P}_{0}$ : Control (without any use of organic pesticides); $\mathrm{P}_{1}$ : neem leaf extract; $\mathrm{P}_{2}$ : soursop leaf extract; $\mathrm{P}_{3}$ : lemongrass extract; $\mathrm{P}_{4}$ : tuba root extract and $\mathrm{P}_{5}$ : kenikir extract. The data were analyzed by using the variance analysis and 5\% of Smallest Differential Difference Test.

\section{Planting}

In two weeks after seeding, the planting is conducted. The samples are selected from the plants which already have 3-4 leaves, picked out from a healthy and uniform growth, and then planted one plant for each polybag.

\section{Neem leaf extract, soursop leaf, lemongrass extract, tuba root and kenikir leaf}

To make the organic pesticide extract, $500 \mathrm{~g}$ of neem leaves, 50 sheets of soursop leaf, $500 \mathrm{~g}$ of kenikir leaves, $500 \mathrm{~g}$ of lemongrass leaves and $500 \mathrm{~g}$ of root of tuba was collected from the field and cleaned. Each of the materials was then smashed and soaked in 5 liters of water for overnight (24 hours), before straining the solution with fabric (cheesecloth). In practice, the filtrate is mixed with water in a ratio of 1: $10(100 \mathrm{ml}$ of water extract into 1 liter of water) with an addition of 1 spoon of detergent as additive before use.

\section{The application of organic pesticide extract}

The plant-based pesticides from neem leaf extract, soursop leaves, lemongrass, tuba root, and kenikir were used by spreading it with hand sprayer to all parts of the plant, and the application was repeated 8 times. The $1^{\text {st }}$ spraying was performed at 59 days after planting (DAP), the second at the age of 66 DAP, the $3^{\text {rd }}$ at age 73 DAP, while the $4^{\text {th }}, 5^{\text {th }}$, and $6^{\text {th }}$ spraying were conducted at the age of 80 DAP, 87 DAP, and 94 DAP respectively.

\section{The care}

Standard plant care procedures were followed, i.e., watering, installation of stake to help plant stands, pruning, and application of fertilizers twice after planting; at one week and 30 DAP. NPK fertilizer was used with a dosage of $2 \mathrm{~g}$ per polybag.

\section{Harvesting}

Fruits which met the criteria of harvest $(80 \%$ ripened fruits, indicated by the solid shape and reddish-green color) were harvested with a harvest interval of 5 days. Fruits were harvested 5 times following the standard criteria and the requisite interval along with their stalk.

\section{Data analysis}

Intensity of disease

The was calculated using the formula:

$$
I=\frac{\sum(n \times v)}{N \times Z} \times 100 \%
$$

Where:

I : The intensity of attack

$\Sigma_{n}$ : Number of leaves at a certain scale

$\Sigma v$ : Scale value observed

$\mathrm{N}$ : Number of all leaves

$\mathrm{Z}$ : The highest scale value

Table 1. The scale of disease intensity

\begin{tabular}{lll}
\hline Scale & Percentage disease attack & The level \\
\hline 0 & 0 & No attack \\
1 & $>0-5 \%$ & Very light \\
2 & $>5-15 \%$ & Light \\
3 & $>15-30 \%$ & Medium \\
4 & $>30 \%$ & Heavy \\
\hline
\end{tabular}

\section{The percentage of fruit damage}

To calculate the percentage of damage to the fruit, they were observed from fruit phase to harvesting. The fruits are considered to be exposed to attack when there is a $\geq 5 \%$ attack. According to Irmansyah et al. (1994), the formula to calculate the affected fruits is as follows:

$$
P=\frac{a}{a+b} \times 100
$$

Where:

$\mathrm{P}$ : Percentage of damage

a : Number of damage fruits

b : Number of healthy fruits

\section{The production}

Production is calculated by weighing the chili pepper after each treatment and for every harvesting. After 5 harvesting, the average of total production (in ton/ha) can be calculated. .

The production for each harvesting is calculated by the formula:

$$
\frac{\text { ton }}{h a}=\frac{1 \text { ha }}{\text { plant distance }} \times \frac{\text { production }}{\text { total plant }}
$$

\section{Data analysis method}

The data obtained were analyzed using variance table, if difference was observed then it was continued by using the Smallest Differential Difference Test (BNT) of 5\% level. 


\section{RESULTS AND DISCUSSION}

\section{The intensity of leaf disease on large chili plants}

This study identified the intensity of leaf disease on large chili plants at $59^{\text {th }}, 66^{\text {th }}, 73^{\text {rd }}, 80$ and $94^{\text {th }}$ DAP. The disease intensity on large chili plants was observed every once a week starting from 59 DAP to 73 DAP. In particular, for the $59^{\text {th }}$ DAP, based on the analysis of variance, the intensity of disease was presented in Table 2 which indicated the apparent difference.

Based on the results of 5\% BNT Test as shown in Table 2 , the intensity of the attack at 59 DAP is significantly different between each treatment. The observation of 59 DAP treatment of $\mathrm{P}_{1}$ and $\mathrm{P}_{5}$ was not significant but significantly different to others. Similarly, $\mathrm{P}_{0}, \mathrm{P}_{2}, \mathrm{P}_{3}$, and $\mathrm{P}_{4}$ were not significantly different but significantly different for the others. The highest percentage $(40.70 \%)$ of attack was found in treatment of $\mathrm{P}_{4}$ (tuba root extract), while the lowest attack was found in $\mathrm{P}_{1}$ at $27.08 \%$.

On the other hand, the results of the use of organic pesticides on the average disease intensity of the leaves showed a significant difference. Based on the results of 5\% BNT Test as shown in Table 3, the intensity of disease of leaves at age of 66 DAP shows a significant difference between each treatment. The highest average (36.43\%.) was found in treatment $\mathrm{P}_{2}$ (soursop leaf extract).

The results of the intensity of leaf disease at 73 days after planting, shows that there is a significant difference of the average intensity of leaf disease, based on the results of the 5\% BNT test (Table 4). The table also shows that the intensity was significantly different among each treatment, though for $\mathrm{P}_{1}$ and $\mathrm{P}_{4}$ there is not any significant difference.

\section{Disease intensity in large chili}

The results of the disease intensity at 80 DAP show a significant difference in the variance between the organic pesticides to the fruit disease intensity. The results of the average disease intensity in each treatment can be seen in Table 5. Based on the results of the 5\% BNT test ( Table 5) only $\mathrm{P}_{1}$ treatment was significantly different compared to the rest of the treatments. The highest average percentage was observed in $\mathrm{P}_{3}$ (lemongrass extract) which is $8.69 \%$, and the lowest average percentage was observed in $\mathrm{P}_{1}$ treatment, which is $2.81 \%$.

The variance of the use of organic pesticide to the average disease intensity on the fruit aged 87 of days after planting showed a significant difference as shown in Table 6.

The results of the variance of organic pesticide to the disease intensity in fruit at age 94 DAP, show a significant difference as shown in Table 7.

The results of the variance due to the effect of organic pesticides to the average of fruit production of chili plants per hectare show a significant difference which can be seen in Table 8.

The result indicates that the use of organic pesticides provides a significant influence on production. $\mathrm{P}_{1}$ treatment shows a great difference from the other treatments; $\mathrm{P}_{0}, \mathrm{P}_{2}$, $\mathrm{P}_{3}, \mathrm{P}_{4}$, and $\mathrm{P}_{5}$. The treatments of $\mathrm{P}_{0}, \mathrm{P}_{2}$, and $\mathrm{P}_{3}$ show a slight difference from each other, as well as $\mathrm{P}_{4}$ and $\mathrm{P}_{5}$.
Table 2. The intensity of disease of 59 DAP

\begin{tabular}{lccccc}
\hline \multirow{2}{*}{ Treatment } & \multicolumn{4}{c}{ The disease intensity after 59 DAP } & \multirow{2}{*}{ Average } \\
\cline { 2 - 5 } & I & II & III & IV & \\
\hline $\mathrm{P}_{0}$ & 40.22 & 45.96 & 41.46 & 42.82 & $42.62 \mathrm{~b}$ \\
$\mathrm{P}_{1}$ & 27.38 & 26.15 & 27.22 & 27.55 & $27.08 \mathrm{a}$ \\
$\mathrm{P}_{2}$ & 27.75 & 48.68 & 36.75 & 48.79 & $40.49 \mathrm{~b}$ \\
$\mathrm{P}_{3}$ & 41.08 & 41.34 & 36.10 & 35.43 & $38.49 \mathrm{~b}$ \\
$\mathrm{P}_{4}$ & 36.21 & 53.02 & 33.50 & 40.05 & $40.70 \mathrm{~b}$ \\
$\mathrm{P}_{5}$ & 32.43 & 35.79 & 33.30 & 34.57 & $34.02 \mathrm{a}$ \\
Average & 34.18 & 41,82 & 34,72 & 38,20 & \\
\hline
\end{tabular}

Note: The value followed by the same letter indicate the insignificant difference in BNT test of $5 \%=7.45$

Table 3. The average disease intensity of 66 DAP

\begin{tabular}{lccccc}
\hline \multirow{2}{*}{ Treatment } & \multicolumn{4}{c}{ The disease intensity after 66 DAP } & \multirow{2}{*}{ Average } \\
\cline { 2 - 5 } & I & II & III & IV & \\
\hline $\mathrm{P}_{0}$ & 49.78 & 38.97 & 49.23 & 41.46 & $44.86 \mathrm{~b}$ \\
$\mathrm{P}_{1}$ & 37.11 & 31.83 & 24.40 & 32.43 & $31.44 \mathrm{a}$ \\
$\mathrm{P}_{2}$ & 40.89 & 34.74 & 33.56 & 36.54 & $36.43 \mathrm{a}$ \\
$\mathrm{P}_{3}$ & 36.35 & 36.53 & 28.57 & 36.21 & $34.42 \mathrm{a}$ \\
$\mathrm{P}_{4}$ & 41.07 & 23.45 & 27.66 & 36.10 & $32.07 \mathrm{a}$ \\
$\mathrm{P}_{5}$ & 33.30 & 35.72 & 34.35 & 36.75 & $35.03 \mathrm{a}$ \\
Average & 39.75 & 33.54 & 32.96 & 36.58 & \\
\hline
\end{tabular}

Note: The value followed by the same letter indicate the insignificant difference in BNT test of $5 \%=7.45$

Table 4. The average disease intensity of 73 DAP

\begin{tabular}{lccccc}
\hline \multirow{2}{*}{ Treatment } & \multicolumn{4}{c}{ The disease intensity after 73 DAP } & \multirow{2}{*}{ Average } \\
\cline { 2 - 5 } & I & II & III & IV & \\
\hline $\mathrm{P}_{0}$ & 36.32 & 23.92 & 35.92 & 36.35 & $33.13 \mathrm{~b}$ \\
$\mathrm{P}_{1}$ & 20.34 & 23.83 & 21.53 & 18.05 & $20.94 \mathrm{a}$ \\
$\mathrm{P}_{2}$ & 34.75 & 25.78 & 31.69 & 35.42 & $31.91 \mathrm{~b}$ \\
$\mathrm{P}_{3}$ & 38.98 & 24.96 & 19.42 & 32.96 & $29.08 \mathrm{~b}$ \\
$\mathrm{P}_{4}$ & 27.58 & 29.50 & 22.47 & 22.45 & $25.50 \mathrm{a}$ \\
$\mathrm{P}_{5}$ & 31.25 & 25.69 & 27.56 & 28.57 & $28.27 \mathrm{~b}$ \\
Average & 31.54 & 25.61 & 26.43 & 28.97 & 28.14 \\
\hline
\end{tabular}

Note: The value followed by the same letter indicate the insignificant difference in BNT test of $5 \%=7.15$

Table 5. Average disease intensity of 80 days

\begin{tabular}{lccccc}
\hline \multirow{2}{*}{ Treatment } & \multicolumn{9}{c}{ The disease intensity after 80 DAP } & \multirow{2}{*}{ Average } \\
\cline { 2 - 5 } & I & II & III & IV & \\
\hline $\mathrm{P}_{0}$ & 7.73 & 8.98 & 8.72 & 10.62 & $9.01 \mathrm{~b}$ \\
$\mathrm{P}_{1}$ & 2.60 & 3.27 & 2.60 & 2.76 & $2.81 \mathrm{a}$ \\
$\mathrm{P}_{2}$ & 10.62 & 4.03 & 3.24 & 8.63 & $6.63 \mathrm{~b}$ \\
$\mathrm{P}_{3}$ & 10.83 & 7.23 & 7.73 & 8.98 & $8.69 \mathrm{~b}$ \\
$\mathrm{P}_{4}$ & 4.03 & 3.66 & 8.63 & 8.72 & $6.26 \mathrm{~b}$ \\
$\mathrm{P}_{5}$ & 7.52 & 3.56 & 5.53 & 6.93 & $5.89 \mathrm{~b}$ \\
Average & 7.22 & 5.12 & 6.08 & 7.77 & \\
\hline
\end{tabular}

Note: The value followed by the same letter indicate the insignificant difference in BNT test of 5\% $=2.96$ 
Table 6. Average disease intensity of 87 DAP

\begin{tabular}{lccccc}
\hline \multirow{2}{*}{ Treatment } & \multicolumn{4}{c}{ The disease intensity after 87 DAP } & \multirow{2}{*}{ Average } \\
\cline { 2 - 5 } & I & II & III & IV & \\
\hline $\mathrm{P}_{0}$ & 8.63 & 10.62 & 8.13 & 17.38 & $11.19 \mathrm{c}$ \\
$\mathrm{P}_{1}$ & 1.83 & 2.76 & 3.93 & 5.06 & $3.40 \mathrm{a}$ \\
$\mathrm{P}_{2}$ & 6.39 & 6.39 & 6.06 & 13.86 & $8.18 \mathrm{~b}$ \\
$\mathrm{P}_{3}$ & 7.23 & 3.66 & 7.23 & 12.24 & $7.59 \mathrm{~b}$ \\
$\mathrm{P}_{4}$ & 3.93 & 3.10 & 8.98 & 11.18 & $6.80 \mathrm{~b}$ \\
$\mathrm{P}_{5}$ & 13.99 & 2.76 & 13.86 & 11.18 & $10.45 \mathrm{~b}$ \\
Average & 7.00 & 4.88 & 8.03 & 11.82 & \\
\hline
\end{tabular}

Note: The value followed by the same letter indicate the insignificant difference in BNT test of 5\%

Table 7. Average disease intensity of 94 DAP

\begin{tabular}{lccccc}
\hline \multirow{2}{*}{ Treatment } & \multicolumn{6}{c}{ The disease intensity after 94 DAP } & \multirow{2}{*}{ Average } \\
\cline { 2 - 5 } & I & II & III & IV & \\
\hline $\mathrm{P}_{0}$ & 37.40 & 30.00 & 34.10 & 39.90 & $35.35 \mathrm{c}$ \\
$\mathrm{P}_{1}$ & 11.26 & 9.53 & 11.18 & 10.97 & $10.74 \mathrm{a}$ \\
$\mathrm{P}_{2}$ & 20.40 & 21.70 & 25.46 & 27.94 & $23.88 \mathrm{~b}$ \\
$\mathrm{P}_{3}$ & 30.26 & 31.56 & 29.14 & 30.26 & $30.31 \mathrm{~b}$ \\
$\mathrm{P}_{4}$ & 18.60 & 17.10 & 15.47 & 15.27 & $16.61 \mathrm{~b}$ \\
$\mathrm{P}_{5}$ & 33.22 & 10.76 & 13.86 & 12.17 & $17.50 \mathrm{~b}$ \\
Average & 25.19 & 20.11 & 21.54 & 22.75 & \\
\hline
\end{tabular}

Note: Values followed by the same letter show no significant difference in the $5 \%$ BNT test

Table 8. Average production of fresh chili peppers $\left(\mathrm{mg} \mathrm{ha}^{-1}\right)$

\begin{tabular}{lcccccc}
\hline \multirow{2}{*}{ Treatment } & \multicolumn{7}{c}{ Number of harvesting } & \multirow{2}{*}{ Average } \\
\cline { 2 - 6 } & I & II & III & IV & V & \\
\hline $\mathrm{P}_{0}$ & 0.19 & 0.24 & 0.40 & 0.36 & 0.15 & $0.27 \mathrm{a}$ \\
$\mathrm{P}_{1}$ & 1.28 & 0.84 & 0.79 & 0.66 & 0.30 & $0.77 \mathrm{c}$ \\
$\mathrm{P}_{2}$ & 0.32 & 0.35 & 0.48 & 0.44 & 0.21 & $0.36 \mathrm{a}$ \\
$\mathrm{P}_{3}$ & 0.21 & 0.26 & 0.46 & 0.40 & 0.21 & $0.31 \mathrm{a}$ \\
$\mathrm{P}_{4}$ & 0.58 & 0.52 & 0.63 & 0.53 & 0.25 & $0.50 \mathrm{~b}$ \\
$\mathrm{P}_{5}$ & 0.53 & 0.46 & 0.66 & 0.58 & 0.22 & $0.49 \mathrm{~b}$ \\
Average & 31.22 & 26.78 & 34.26 & 29.85 & 13.45 & \\
\hline
\end{tabular}

Note: Values followed by the same letter show no significant difference in the $5 \%$ BNT test. $=0.19 \%$

\section{Discussion}

\section{The intensity of leaf attack on large chili plants}

The result indicated a significant influence of the use of organic pesticide to the intensity of the disease on the leaves of large chili plants (Capsicum annum L.) at $59^{\text {th }}$, $66^{\text {th }}$ and $73^{\text {rd }}$ DAP. In the control treatment of $\mathrm{P}_{0}$ (without treatment) the intensity of the attack showed the highest average attack compared to other treatment. In chili plants treated with neem leaf extract $\left(\mathrm{P}_{1}\right)$; soursop leaf extract $\left(\mathrm{P}_{2}\right)$; lemongrass extract $\left(\mathrm{P}_{3}\right)$; tuba root extract $\left(\mathrm{P}_{4}\right)$; kenikir extract $\left(\mathrm{P}_{5}\right)$, showed a positive response to the intensity of the attack. In $\mathrm{P}_{1}$ treatment (neem extract) gave the lowest average percentage of attack intensity of all treatments at age 59, 66 and 73 (DAP). This shows that the influence of the active ingredient of the leaves of the neem namely azadirachtin is the best source for biopesticides.

\section{Percentage of damage to chili fruit}

The common disease in chili is anthracnose (Colletotrichum capsici L.). Based on the observation of anthracnose disease attacks at the aged of 80, 87 and 94 DAP, there is a distinct result among them. According to Saefudin (2003), anthracnose disease attacks chili plants in the generative phase. Referring to the control treatment, some of the young chili fruits fall off due to anthracnose attacks. The attacks on young fruit tend to be more vulnerable than semi-ripe fruit (Rahman et al. 2011). In addition, the control treatment $\left(\mathrm{P}_{0}\right)$ did not receive preventive treatment so that it gave a large chance of $\mathrm{C}$. capsici spores which had infected the chili fruit to develop well (Serra et al. 2002; Shafique et al. 2018)

The effect of application of several organic pesticides of neem leaf extract $\left(\mathrm{P}_{1}\right)$; soursop leaf extract $\left(\mathrm{P}_{2}\right)$; lemongrass extract $\left(\mathrm{P}_{3}\right)$; tuba root extract $\left(\mathrm{P}_{4}\right)$; kenikir extract $\left(\mathrm{P}_{5}\right)$, showed different results, as seen from the average of each treatment. The decrease in the percentage of damage to the fruit, especially in the treatment of neem leaf extract $\left(\mathrm{P}_{1}\right)$, where the average fruit damage that occurs is the smallest average of other treatments. This is because neem leaf extract contains compounds that can suppress the growth of the disease. One of the active ingredients contained in the neem is nimbin. These compounds act as anti-microbial agents such as antiviral, bactericidal, fungicides, which are very useful in controlling plant diseases (Shafique et al. 2018). Further, a neem fungicide can be used for preventive measures in the early stages of fungal disease symptoms. Neem leaf extract sprays prevent spore germination. Toxic compounds such as azadirachtin, neem and nimbidine are known to function as antifungals that can inhibit the growth and development of fungi and can inhibit the formation of sprout tubes from mold spores of C. capsici so that mold spores cannot germinate or not able to infect the fruit. This can also reduce the intensity of anthracnose disease attacks on chili (Shafique et al. 2012; Zaheer et al. 2012). Overall the administration of neem leaf extracts significantly affected the intensity of anthracnose disease attacks on chili.

\section{Production of fresh fruit per hectare}

Based on observations of the average fresh fruit production per hectare, the use of organic pesticides indicates a significant result, by reducing the percentage of attacks. Production results are strongly influenced by the types and varieties used, the growing season, the way to grow crops and other formation factors. But production results are also strongly influenced by the percentage of pest attacks and the forms of control used. It is proven that the percentage of anthracnose that attacks chili plants greatly affect the yield, both in quality and quantity. The usage of some plant pesticides applied to chili plants can reduce the rate of anthracnose infections. As the control treatment, the average of production is $0.27 \mathrm{mg} \mathrm{ha}^{-1}$. This is presumably due to the diseases which cause the production decrease. The average fresh fruit production per hectare in the case of neem leaf extract $\left(\mathrm{P}_{1}\right)$ was $0.77 \mathrm{mg} \mathrm{ha}^{-1}$; whereas it was $0.36 \mathrm{mg} \mathrm{ha}^{-1}$ in the case of Soursop leaf extract $\left(\mathrm{P}_{2}\right)$ usage; The effect of lemongrass extract $\left(\mathrm{P}_{3}\right)$ on 
the average fresh fruit production resulted in a yield of 0.31 $\mathrm{mg} \mathrm{ha}{ }^{-1}$ whereas in the case of Tuba root extract $\left(\mathrm{P}_{4}\right)$ usage the average fresh fruit production per hectare was $0.50 \mathrm{mg}$ ha $^{-1}$; Kenikir $\left(\mathrm{P}_{5}\right)$ extract usage resulted in an average fresh fruit production per hectare of $0.49 \mathrm{mg} \mathrm{ha}^{-1}$. The results of the study showed that the application of neem leaf extract treatment had a significant effect on the average fruit production per hectare.

It is clearly seen that based on the production, the treatment of neem leaf extract $\left(\mathrm{P}_{1}\right)$ provides the best result. The active compounds, namely the triterpenoids, could be the reason behind the lowering of pathogenic attack. In this regard, the best source for biopesticides is azadirachtin. Based on the results of research conducted, it can be concluded that all types of organic pesticides used in this study have the ability to control attacks on large chili plants. However, compared with soursop leaf extract, lemongrass extract, tuba root extract, and kenikir extract, neem leaf extract has a higher effectiveness against the attacks.

\section{ACKNOWLEDGEMENTS}

This research was funded by The Ministries of Research, Technology and Higher Education, Indonesia. We thank our colleagues who provided useful feedbacks, input, and suggestion for this research, particularly to those who helped in data collection.

\section{REFERENCES}

Ahmad N, Sarwar M, Khan GZ, Tofique M, Salam A. 2011. Efficacy of some plant products and synthetic chemicals to manage the outbreak of mealybug (Maconellicoccus hirsutus) in cotton. J Agric Biol Sci 3 (1): $16-21$.

Ahmed NU, Park JI, Jung HJ, Kang KK, Hur Y, Lim YP, Nou IS. 2012. Molecular characterization of stress resistance-related chitinase genes of Brassica rapa. Plant Physiol Biochem 58: 106-115.

Chopan M, Littenberg B. 2017. The association of hot red chili pepper consumption and mortality: A large population-based cohort study. PLoS ONE 12 (1): e0169876. DOI: 10.1371/journal.pone.0169876

Fatima K, Wisdom K, Tembo L. 2015. Efficacy of garlic (Allium sativum) and red chili pepper (Capsicum annum) extracts in the control of red spider mite (Tetranychus urticae) in tomatoes (Lycopersicon esculentum). Asian J Appl Sci 3 (1): 2321-893.

Ferniah RS, Kasiamdarai RS, Priyatmojo A, Daryono BS. 2015 Expression of Class II Chitinase Gene in Chili (Capsicum annuum L.) as response to Fusarium oxysporum pathogen attack. Asian J Plant Pathol 9 (3): 142-147.
Irmansyah, Mardius, Zulpadi. 1994. Ketahanan tiga varietas bentuk buah cabai terhadap penyakit antraknose di Sumatra Barat. Jurnal Fitopatologi 4 (1): -. [Indonesian]

Kantar MB, Anderson JE, Lucht SA, et al. 2016. Vitamin variation in Capsicum spp. provides opportunities to improve nutritional value of human diets. PLoS One 11 (8): e0161464. DOI: 10.1371/journal.pone.0161464.

Muzemu S, Mvumi BM, Nyirenda SM, Sileshi GW, Sola P, Chikukura L, Kamanula JF, Belmain SR, Stevenson PC. 2011. Pesticidal effects of indigenous plant extracts against rape aphids and tomato red spider mites. African Crop Sci Proc 10: 171-173.

Pahla I, Moyo M, Muzemu S, Muziri T. 2014. Evaluating the effectiveness of botanical sprays in controlling aphids (Brevicoryne brassicae) on rape (Brassica napus L.). Intl J Agron Agric Res 5 (1): 1-6.

Rabindranath G, Tendulkar, Tagore NK. 2016. Effect of anthracnose and powdery mildew pathogens on plant morphology. African J Biol 3 (7): 265-268

Rahman MS, Akhter MS, Maya MA, Rahman AHMA, Akanda AM. 2011. Field resistance of chilli cultivars against anthracnose disease caused by Colletotrichum capsica. Thai J Agric Sci 44 (4): 243-250.

Reddy MVB, Sasikala P. 2013. Capsaicin and colour extraction from different varieties of green and red chili peppers of Andhra Pradesh. Intl J Adv Sci Tech Res 2: 554-572

Sarwar M. 2013. The Inhibitory properties of organic pest control agents against aphid (Aphididae: Homoptera) on canola Brassica napus L. (Brassicaceae) under field environment. Intl J Sci Res Environ Sci 1 (8): 195-201.

Sarwar M. 2015. The killer chemicals for control of agriculture insect pests: The botanical insecticides. Intl J Chem Biomol Sci 1 (3): 123128

Saxena A, Raghuwanshi R, Gupta VK, Singh HB. 2016. Chilli anthracnose: The epidemiology and management. Front Microbiol 7: 1527.

Serra I, Yamamoto M, Calvo A. 2002. Association of chili pepper consumption, low socioeconomic status and longstanding gallstones with gallbladder cancer in a Chilean population. Intl J Cancer 8 (4): 7 11.

Shafique S, Shafique S, Ahmad A. 2018. Biochemical and molecular screening of varieties of chili plants that are resistant against Fusarium wilt infection. Eur J Microbiol Immunol 8 (1): 12-19.

Shafique. S, Abdul MR. 2012. Cymbopogon citrates: a remedy to control selected Alternaria species. J Med Plants Res 6 (18): 79-85.

Sopialena. 2014. Efektivitas beberapa cara penularan virus mosaic pada tanaman cabai. Jurnal Agrifor 8 (2) : 207-212. [Indonesian]

Sopialena. 2016. Efektifitas Beberapa Fungisida terhadap Perkembangan Penyakit dan Produksi Tanaman Cabai (Capsicum frutescens). Jurnal Agrifor 15 (1): 117-130. [Indonesian]

Suyadi, Sopialena, Nurdiana J, Suryadi A, Rosfiansyah, Waluyo S. 2017. Genus Nematoda Entomoparogen pada lahan lebak padi sawah (Oriza sativa L.) di Kecamatan Muara Wis, Kabupaten Kutai Kartanegara. Proceeding of Konferensi Antarbangsa Islam Borneo. Mulawarman University, Samarinda, 25 September 2017. [Indonesian]

Thakur H, Jindal SK, Sharma A, Dhaliwal MS. 2018. Chilli leaf curl virus disease: A serious threat for chilli cultivation. J Plant Dis Prot 125 (3): 239-249.

Zaheer Z, Shafique S, Mehmood T. 2012. Antifungal potential of Parthenium hysterophorus L. plant extracts against Fusarium solani. Sci Res Ess 7 (20): 49-54.

Zhu Z, Luo Z, Ma S, Liu D. 2011. TRP channels and their implications in metabolic diseases. Pflugers Archiv: Eur J Physiol 461 (2): 211-223. 